\title{
Peace Education Practices in Pre-Service Teacher Training Programs: and Analysis
}

\author{
Mr. Sufi Amin \\ Research Scholar, Department of Education, International Islamic \\ University, Islamabad \\ Prof. Dr. N. B. Jummani
}

Dean Faculty of Social Sciences, International Islamic University, Islamabad

Dr. Sheikh Tariq Mahmood

Department of Education, International Islamic University, Islamabad

\section{Khan Raziq}

PhD Scholar, Department of Education, International Islamic University, Islamabad

\section{Mr. Muhammad Ayoob Khan Babar}

Research Scholar, Department of Education, International Islamic

University, Islamabad

doi: 10.19044/esj.2016.v12n25p323 URL:http://dx.doi.org/10.19044/esj.2016.v12n25p323

\begin{abstract}
This study was designed to investigate peace education in pre-service teacher training programs in Khyber Pakhtunkhwa, Pakistan. The objectives of the present study to find out:( a) to examine prevailing practices of peace education in pre-service teacher training programs in Khyber Pakhtunkhwa Pakistan. (b) To evaluate the views of teacher Educators regarding the need of peace education in pre-service teacher training programs in Khyber Pakhtunkhwa Pakistan. (c) To suggest way of integrating peace education in pre-service teacher training programs in Khyber Pakhtunkhwa Pakistan. Using Survey method the data were collected through questionnaire from 245 teachers using simple random technique. A questionnaire was developed to investigate the opinions of the participants of the study. The data was analyzed by using the mean score, frequency and percentage.
\end{abstract}

Keywords: Peace, Peace Education, Analysis, Practices, Pre-Service teacher training

\section{Introduction}

In all societies violence is existing in different forms, which is a key problem. From previously five decade the education have main concerned 
about this problem, which have claimed that education has an obligation to address the matters through education in schools, colleges, universities, teachers training programs and other training programs, which are connected to the aims of peace. The requirements of students in Pakistani classrooms has erased, therefore various students not merely trust on the education system for instructional as well as educational learning, but are using it as an opening to handle with problems they have been undergoing in their lives. Peace education is a merging as well as complete idea that pursues to endorse a universal vision of education. Though, its significance is intimately part of as well as is extremely reliant on appropriate specificity. According to UNESCO, peace education is more effective as well as eloquent when implemented according to the social and cultural perspective and the requirements of a country. It should be developed by its cultural and spiritual values together with the worldwide human values. It should also be internationally applicable (UNESCO, 2009).

So, the core purpose of peace is freedom from violence as and conflict, which were develop the source of silence. Thus, peace education is a practices to develop the awareness, actions, capacities as well as manner of life to upsurge and keep this psychosomatic silent. Everybody which were living in this world, they have regularly pebbledash tension as well as unease, financial, dogmatic, general as well as ethical. Clashes of nations, cultural-conflict as well as socio-economic conflicts are out to determination humanity on the verge of demise. In this hard stage, regeneration of an idea of peace is the requirement of the time. In school period Peace education can determined a wide technique in recommending training in the modern society (Charles \& Philip's, 2013). In everywhere in this contemporary world, we see wars before reconciliation, misappropriation previously sensible circulation of wealth, cruelty instead of comparable deed and reverence, as well as fight before collaboration. Particularly, wars as well as fierceness not ever look to end as well as can smoothly invulnerable in the name of equality. There have been in feeling near the outdated viciousness, creation fierceness appearance usual, depressing the verge (Galtung, 2006). This philosophy of ferocity inevitably have an inordinate consequence on children, prompting them fear as well as nervousness, regularly concluded their everyday exists in city cultures as well as the media (Hales \& Herbert, 2011).

\section{Literature review}

Peace education as the name of those actions, which promotes awareness, abilities as well as outlooks, which is compulsory to discover perceptions of peace, and investigate the hindrances of peace, equally in peoples as well as in their cultures, by the helps of this to resolution of wars in peaceful manner, as well as to study the traditions of building as well as 
supportable different scenarios (Hooper, 1990). He separate peace education, similarly to UNICEF, which stress sanctioning peoples with aptitudes, point of view as well as considerate, it is the name of attitudinal as well as a practice involving skills. Rendering to them, this process contains sanctioning peoples towards their skills, viewpoints in addition to consciousness to make an innocuous world along with hypothesis a supportable heaven. This awareness explains nonviolence, love, understanding and esteem for entire life (Strokes, 2012).

Henry (2012), cited that, different schools system have developed the several types of presentation as well as circulation of peace education programs in schools. According to Sharma (2010) \& Wagers (2012), mentioned that, the present peace education and their requirement is that to trained and educate the teachers, to update their syllabus according to the needs of the society, as well as to create such types of atmosphere in classrooms and out sides the classrooms in our societies. It is a study of preservice teachers training in the field of peace education is imitated to be significant as well as conclusive, by the help of this, that how educators study and flourish in real classroom as well as in school environments (Dany, 2010). In the present time the Educationist has great about peace education, that to promote peace education schools and teacher is the key indicators in the development of peace education in classroom (Rose, 2004); by preparation of pre-service teachers in the field of peace education they can empower them to the framework of the theme in primary as well as secondary schools as well as other scholastic institutions in our country. It's the need of the day to incorporate peace education in every obligatory topic in pre-service teachers training programs, and it's become the portion of courses of prospective teachers in our country. Showed that, peace education presented in pre-service teacher training programs can initiate a tradition of peace for consistent bases, beginning them in prospective teachers training institutions as well as restricting in the schools along with civilizations Herath, (2012).

United Nations and its organizations has been properly introduced Peace education in everywhere the world, key determination of the peace education is that to encourage peace is universally, into this work altered associations are functioning to grow peace education in everywhere the earth. Some of these organization who work in the field of peace education in whole earth, they were: UNESCO, UNICEF, CCTP, HAP, as well as GCPE. Best (1990), Rose (2005), \& Deny (2010), all of the scholars have explains, peace education ant its definitions of peace education, aims of peace education as well as objectives of peace education, contents of peace education as well as pedagogy of peace education. These philosopher developed models of peace education, for example, Deny (2010), Roots (2006), \& Kings (2011), they were develop altered model of peace education in the whole world, these 
model were developed according to the needs and requirement of the country in everywhere the world. They were elucidate the progress of the peace studies near the end of 20th century, and its demand, that it has an important symbolical connotation with peace activities, peace investigation, as well as peace education by the mechanism of campaigners as well as researchers to restraint individuals about the danger of ferocity. In educational institutions, it is the duty of teachers to indorse these proceedings to provide scholars indulgent into how to achieve wars in various circumstances (Henry, 2012).

\section{Objectives of the study}

1. To investigate Current practices of peace education in pre-service teacher training programs in Khyber Pakhtunkhwa Pakistan.

2. To identify the need of peace education in pre-service teacher training programs in Khyber Pakhtunkhwa Pakistan.

3. To estimate the views of teacher regarding the need of peace education in pre-service teacher training programs in Khyber Pakhtunkhwa Pakistan.

\section{Research Questions}

1. What types of practices are reflected in pre-service teacher training programs regarding peace education in Khyber Pakhtunkhwa Pakistan?

2. Whether peace education is one of the important requirements of preservice training programs in Khyber Pakhtunkhwa Pakistan?

3. What are the views of teachers regarding the need of peace education in Khyber Pakhtunkhwa Pakistan?

\section{Research Design}

It was a descriptive study, this research was concerned with the prevailing status of the subject under research. Sufficient information has been used in this investigation as well as data has been also tabulated in the form of figure and charts. This research elaborate collection of information from the targeted respondents. Generally, descriptive data is collected by the help of questionnaires. Yet, this investigate based on questionnaire. A Five point Likert Scale was used in questionnaire, and questionnaire was developed and each statement was followed by five point.

\section{Data Analysis and Interpretation}

Reliable, valid, accurate and well-designed instrument was used in the collection of information for this investigate. The research instrument was pretested in the form of pilot study, thus ensuring the validity as well as reliability of the developed research instrument. Research instrument was administered to the sample respondents only after thorough validity and authentication checks. The data was collected by the help of questionnaire, and the collected 
data were accurately prepared, arranged, examined as well as understood, according to modern statistical methods ( e.g, Frequency, percentages as well as Mean Score), after that the researcher explain every and each tables and figures.

Table 1: Showing the overall results of respondent regarding the practices of peace

$\begin{array}{clccc}\text { S.No } & \text { Indicators } & \text { N } & \text { Agree } \% & \text { Disagree } \% \\ 1 & \text { Conflict resolution } & 250 & 39 & 61 \\ 2 & \text { Global Awareness } & 250 & 44.4 & 55.6 \\ 3 & \text { Constructive thinking } & 250 & 40 & 60 \\ 4 & \text { Human rights } & 250 & 65.5 & 34.5 \\ 5 & \text { Self-awareness } & 250 & 62.3 & 37.7 \\ 6 & \text { Boost up human dignity } & 250 & 55.5 & 44.5 \\ 7 & \text { Positive attitudes } & 250 & 37.7 & 62.3 \\ & \text { Overall Percentage } & & 49.2 \% & 50.8 \%\end{array}$

Table 1 revealed that $39 \%$ of the teachers agree and $61 \%$ teachers were disagree. It can be concluded that most of the teachers were aware about conflict resolution. $44.4 \%$ of the teachers agree and $55.6 \%$ teachers were disagree. It can be concluded that most of the teachers were not aware about global awareness. $40 \%$ of the teachers agree and $60 \%$ teachers were disagree. It can be concluded that most of the teachers were not aware about constructive thinking. $65.6 \%$ of the teachers agree and $34.5 \%$ teachers were disagree. It can be concluded that most of the teachers were aware about human rights. $62.3 \%$ of the teachers agree and $37.7 \%$ teachers were disagree. It can be concluded that most of the teachers were not aware about self-awareness. $55.5 \%$ of the teachers agree and $44.4 \%$ teachers were disagree. It can be concluded that most of the teachers were not aware about boost up human dignity. 37.7\% of the teachers agree and $62.3 \%$ teachers were disagree. It can be concluded that most of the teachers were aware about positive attitudes. It is concluded that from the overall percentage that $49.2 \%$ of teachers were agree and $50.8 \%$ of teachers were disagree about the practices of peace education in PSTT.

Table 2: showing the mean values, Std. Deviation and Std. Error of Mean of practices

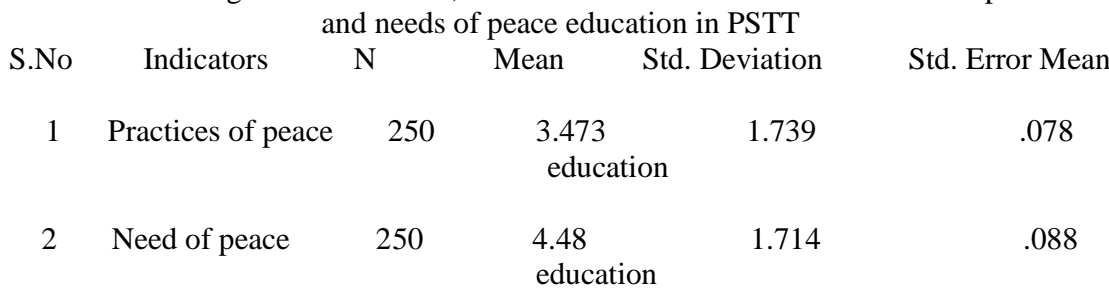


Table 2 present that the mean value of practices of peace education in PSTT is 3.473, and the mean values of need of peace education in PSTT 4.48. So, it is concluded that most of teachers were agree about the need of peace education in PSTT as compare to practices of peace education in PSTT.

Table 3: Showing the $t$ test result on practices of peace education in PSTT in term of

\begin{tabular}{|c|c|c|c|c|c|c|}
\hline \multirow{3}{*}{ Gender } & \multicolumn{5}{|c|}{ gender } & \multirow[b]{2}{*}{$\mathrm{p}$ Value } \\
\hline & $\mathrm{N}$ & Mean & Std. Dev & Std. Errol & $t$ value & \\
\hline & Male & 135 & 4.11 & 1.753 & $\begin{array}{c}0.121 \\
4.235\end{array}$ & \multirow{2}{*}{0.0001} \\
\hline & Femal & 115 & 3.38 & 1.321 & 0.083 & \\
\hline
\end{tabular}

Table 3 reflected that the mean score of male teachers on the practices of peace education is higher than female teachers, as well as the t value 4.235 is significant at 0.05 , level of significant difference between mean score of male teacher. So it can be concluded that male teachers were significantly more than female teachers on the practices of peace education in PSTT.

\section{Discussion}

The key concern of this investigation was about the Peace Education Practices in Pre-Service Teacher Training Programs: And Analysis, the objective of this study was: (a) to investigate Current practices of peace education in pre-service teacher training programs in Khyber Pakhtunkhwa Pakistan. (b) To identify the need of peace education in pre-service teacher training programs in Khyber Pakhtunkhwa Pakistan. (c) To estimate the views of teacher regarding the need of peace education in pre-service teacher training programs in Khyber Pakhtunkhwa Pakistan.

This research explain that a large number of the teachers were not aware about peace education and its practices n PSTT. The awareness about the mechanisms of peace education and its practices in PSTT was examined. The result of the research showing that a large number of the teachers were not aware the practices and need of peace education in PSTT. Whereas, further shown that male teachers have better awareness as compare to female.

\section{Conclusion}

The key concern of the prevailing research about the current practices of peace education in pre-service teacher training programs in Khyber Pakhtunkhwa, Pakistan. In this research the scholar measured the existing practices of peace education in pre-service teacher training programs in Khyber Pakhtunkhwa, Pakistan. This investigation concluded that most of the participants have optimistic outlooks about the recent practices of peace education in pre-service teacher training programs in Khyber Pakhtunkhwa, Pakistan. The investigator measured the reactions of the participants, that peace education practices is not totally present in our national curriculum of 
pre-service teacher training programs, peace education exist in different parts in the curricula of peace education in pre-service teacher training programs in Khyber Pakhtunkhwa, Pakistan, in different subject, for example, classroom management, ed educational psychology, educational management as well as leadership.

The need of peace education in pre-service teacher training programs in Khyber Pakhtunkhwa, Pakistan, was second objective of the current research. According to this, the participants have an optimistic outlooks about the need of peace education in pre-service teacher training programs in Khyber Pakhtunkhwa, Pakistan. In all over the world, especially Pakistan has face challenges of conflict as well as war's in Khyber Pakhtunkhwa, Pakistan. It is the requirement of the present day to develop peace education in our teachers by the help of teacher they can promote among students as well as in society, because teacher plays very important roles in our society.

Opinions of teachers were examined in the current investigation regarding need of peace education in pre-service teacher training programs in Khyber Pakhtunkhwa, Pakistan. The overall result of the research reflected that, the teachers have positive attitudes about peace education in pre-services teachers training programs in Khyber Pakhtunkhwa, Pakistan. According to the views of teachers about Peace education in pre-service teacher training program in Khyber Pakhtunkhwa, Pakistan, by the help of teacher training programs promote, we promote all components of peace education into our pre-service teacher in the stage of training. According to the views of teacher to integrate peace education in our teacher training programs especially in Khyber Pakhtunkhwa, Pakistan. Also integrate Peace education is a compulsory course in our pre-service teacher training programs in Khyber Pakhtunkhwa, Pakistan, as well as in all over the country.

\section{Recommendations}

After the finding and conclusion the researcher recommend the following recommendations, which were:

1. To integrate peace education and its components in our pre-service teacher training programs in Khyber Pakhtunkhwa, Pakistan.

2. To Improvement in the development of a suitable peace education curriculum in pre-service teachers training education in Pakistan. To bring positive change in our pre-service teachers to promote peace education.

3. Provide systems as well as skills that develop peace education at preservice teacher education in Pakistan. 


\section{References:}

Best, K. (1990), Building a Global Civic Culture: Education for an Interdependent World (Syracuse, N.Y: Syracuse University Press).

Charles.H. \& Philip's. .L. (2013), Peace Education at School Level-Needs and Means. Golden Research Thoughts Vol. 2 Issue 12.

Dany, K. (2010). Professionalization of teacher education in India: A critique of teacher education curriculum reforms and its effectiveness, 1-13.

Galtung, J. (2006). Peace by peaceful means: Peace and conflict, development and civilisation. International Peace Research Institute. London: Sage.

Hales, K. \& Herbert, M. (2011), Primary Review: Community Soundings. Cambridge: University of Cambridge, Faculty of Education.

Henry, N. (2012). Institutionalizing critical peace education in public schools: A case for comprehensive implementation. Journal of Peace Education, Vol.8, No.3: 225-242.

Herath, F. (2012). A Baseline survey report on school-based Peace Education and Guidance and Counseling in Secondary Schools in Northern Uganda, 1-60.

Hooper, R. (1990). Understanding the field in education for peace: Issues, Principles and practices in the classroom. London and NY: Routledge. Kings, L. (2011), 'Developing Peace Education Programs: Beyond Ethnocentrism and Violence', Peace Prints: South Asian Journal of Peace building, 1 (1).

Rose, B.N. (2005). Education for a culture of peace in a gender perspective. Paris: UNESCO Publications.

Roots, H. (2006), 'An Integral Model of Peace Education', in A. Wenden (ed.), Educating for Social and Ecological Peace (New York: SUNY Press), 77-98. Sharma, F. (2010). A survey of civil society peace education programmes in South Asia. Educational Policy Research Series, Vol. I, No 2: 1-74.

Strokes, H. (2012), 'History of Peace Education', in and Ed. Cairns G. Salomon (ed.), Handbook on Peace Education (NY: Psychology Press), 11-20.

Wager, T.F. (2012). The search for balance: Understanding and implementing yoga, peace, and democratic education. Journal of Peace Education and Social Justice, Vol. 5, No. 2: 216-234.

United Nations Education, Scientific and Cultural Organisation, 2009. Peace education framework for teacher education, IN/2005/ED/6. New Delhi: UNESCO. 